\title{
The Quest for Political Liberation in Post-Colonial Africa: A Philosophical Analysis of the Role of the 'Indigenous' In the Re- Making Of Africa
}

\author{
Henry Ovwigho Ukavwe Ph.D. \\ Lecturer of Philosophy Department of General Studies Plateau State University, Bokkos, Plateau State, Nigeria
}

\begin{abstract}
This work captures the lethargic inertness of post-colonial Africa by implicating the disillusionment of the post-colonial African dream for the African crisis. It argues that the quest for political liberation in Africa which translated into nationalist movements incited in the people the hope for a new era of basic rights and freedom that will come only with political liberation in a post-colonial Africa. On the contrary, the realisation of political freedom in Africa did not yield the expected results. The paper argues that the situation has immersed Africa and the Africans in a disillusionment which has occasioned Afro-pessimism with a worsened political dependence of Africa on her erstwhile colonial masters. In consideration of this situation, the paper adopts philosophical analysis to expose the fact that the concept of freedom sought by the nationalists was too narrow for while African dependence on the colonial powers was political, economic, social, religious, cultural, moral, and otherwise, the independence emphasised and pursued by the African nationalists was mere political liberation. The paper makes a proposal for the role of the 'indigenous' in the re-making of Africa by arguing that the inherited colonial arrangement cannot solve the African problem rather the African state and its system must be founded on an African platform, that is, on African culture and context in order to achieve the independence ideas.
\end{abstract}

Keywords: Independence, 'Indigenous', Nationalist Movements, Political Liberation, Post-colonial Africa, Remaking of Africa.

\section{Introduction}

The African peoples disproportionately suffered and endured indescribable crisis in their tragic encounter with the European world. This encounter is indexed by colonialism, the imperial occupation of most parts of Africa coupled with the forced administrations of its peoples and the resilient and enduring ideologies and practices of European cultural superiority and racial supremacy. ${ }^{[1]}$ So, it is misleading to adopt, for instance, Ali Mazrui's "episodic" theory of African colonialism which implies, inter alia, the attempt to limit the colonial period to the brief interlude between the 1884 Berlin Conference that partitioned and legitimised European occupation of Africa and the early 1960s when most African countries attained constitutional decolonisation. Such theory argues that the European occupation of Africa has been shallow rather than deep, transitional rather than long-lasting, and thus had very little impact. ${ }^{[2]}$

Against this theory, the colonial period in Africa is marked by horror and violence, spanning from the beginning of the fifteenth century into the first half of the twentieth century. In fact, colonialism involves "the direct and overall subordination of one country to another on the basis of state power being in the hands of the dominating foreign power." ${ }^{[3]}$ As such, it strives "to keep the colonial people in political subjection; and to make possible the maximum exploitation of the people and the country's resources. ${ }^{\text {"[4] }}$ Thus, the whirling vortex of commercial interests of individuals and institutions, aimed at the extraction of natural resources and raw materials, orchestrated the sporadic and systematic maritime commercial incursions into Africa by European fortune seekers. In the sequel, the British government who initially kept a distance from these adventurers later adopted many of their earlier dreams and ambitions to justify colonial expansion. In this regard, Aijaz Ahmad observed that:

commercial developers and adventurers like Cecil Rhodes in Southern Africa,

Frederick Luggard in Nigeria, and Hugh Cholmondeley Delamere in Kenya,

played important roles in later British colonisation on the African continent. ${ }^{[5]}$

Regrettably, however, colonialism in Africa unfolded in a successive chain of elements of dislocations which delegitimized the traditional values and dislocated the African economy, while neo-colonialism persistently weakens the African states. In short, for Abiola Irele, colonialism advanced the 'rape' of Africa in a disguised but plundering form, thereby severing the disorganisation of the colonised people to suit the interests of the colonial powers, at the peril of Africa. ${ }^{[6]}$ It is not surprising, therefore, that colonialism imposed on Africa 
its historic, cultural, political, and economic subordinate status, which to this day defines, in all spheres of life, the situation of the present. ${ }^{[7]}$

Consequently, the quest for political liberation in post-colonial Africa was adumbrated by the African liberation struggle which translated into and become ensconced as revolutions and nationalist movements that would crystallise in constitutional decolonisation spearheaded by notable figures like Kwame Nkrumah, Senghor, Sekou Toure, Nnamdi Azikiwe, etc. As such, the anti-colonial struggles expressed a dream of independence; the quest for political liberation - a tall hope which the people had - in post-colonial Africa.

Furthermore, the quest for political liberation incited in the Africans an expectation of "a new era of basic rights and freedom long denied under foreign or settler rule."[8] As such, they sought and pursued independence and had constant reverie of a post-colonial Africa with a fundamental expectation of the termination of the heinous colonial rule and the attainment of freedom from the oppressive colonizers. J.F. Ade Ajayi, a renowned historian, captured the mood, expectation and faith of the African peoples in the postcolonial dream that:

Insofar as they appreciated what was involved in the independent movement, their basic expectation was to see an end to unpredictability and irrationality of the white man's world.... Their notion of freedom was not an abstract ideal, but a catalogue of specific wants: freedom from unjust and incomprehensible laws and directives ... and freedom to be left alone to live their lives and seek their own goals.... ${ }^{[9]}$

Thus, the terms "liberation" and "freedom" the proud and popular slogans with which the legacy of African political liberation struggle was fostered. The anti-colonial struggle eventually culminated in different nationalist ideologies with their credo professed and pursued by different nationalists and nationalist movements.

\section{Nationalist Ideologies And Movements}

African nationalist ideologies and movements were basically anti-colonial struggles characterised as a quest for freedom, epitomised in political freedom. Thus, freedom is a prime value in African political struggles. In fact, for Jean-Paul Sartre, "we only become what we are by the radical and deep seated refusal of what which others have made of us." ${ }^{[10]}$ Consequently, freedom or liberty implies the absence of restraint on doing what one chooses or what one would choose to do if he knew that he could. Although the concept of freedom is nebulous and hard to grapple with, it is better understood in two senses - "freedom to" act and "freedom from" restraint.

However, the quest for political freedom has pre-occupied the Africans for long owing to their colonial encounters with the Western world. For instance, as far back a 1914, Marcus Garvey had thought that Africans have battered themselves physically and psychologically for long in the hands of European hegemony and domination. He submitted that the Africans need political liberation to unite them, give them a direction and improve their condition. Consequently, he founded the Universal Negro Improvement Association and African Communities (Imperial) League (UNIA-ACL) in August, 1914. His aim was to establish Africa with an absolute government of its own. Thus, he proposed a "Back to Africa" movement which aimed at an independent African nationality. In other words, Garvey proposed the colonisation of Africa by Africans with the aim of establishing a brotherly corporation in Africa where, to borrow from Claude Ake, Africans will pursue objectives they have set by themselves "in their own interest and by means of their own resources." [11]

The granite truth is that Garveyism, that is, the philosophy or ideology of Marcus Garvey had decisive influence on African nationalist movements. Simply put, it contributed enormously to the development of the African consciousness and a sense of dignity and self worth by the Negroes. No wonder Martin Luther King described Garvey as the first man on a mass scale and level to give millions of Negroes a sense of dignity and destiny and make the Negro feel he was somebody. Also, the concept of the "United States of Africa" which has a vision of possible future unification of Africa as a national and sovereign federation of states was first used by Garvey in 1924 in a poem titled "Hail United States of Africa." It is very important to mention here also that Garvey's ideas deeply influenced the birth of the Pan-Africanist movement. Let us now briefly discuss (1) PanAfricanism, and (2) Negritude, as examples of nationalist ideologies and movements.

2.1 Pan-Africanism: Pan-Africanism is a socio-political worldview, a philosophy and a movement which seeks the unification of native Africans and African Diasporas as part of a global African community. Although it conceptually implies "All-Africanism", Pan-Africanism is not merely a concept rather it is an ideology and principle for action of the African people. Thus, George Padmore, an articulator of Pan-Aficanism conceives it as "a dynamic political philosophy and guide to action for Africans in Africa who were laying the foundations of national liberation organisations." ${ }^{[12]}$ In the same vein, B.C. Okolo argues that the foundation for the quest for political liberation of Africa was laid in the Pan-African Movement. According to him, "it was at once a vision of hope and liberation as well as a philosophy of social action for the black man or the African." ${ }^{\text {,13] }}$ Thus, PanAfricanism, to a great extent, manifests the fraternal solidarity among the Africans and, like Horace Campbell 
opined, "the ideas of Pan-Africanism emerged out of the ravages of imperialism, racism, slavery and colonialism." $"[14]$

Furthermore, in his work, Africa for the Africans, Edward Wilmort Blyden (1832-1912), a devoted Pan-Africanist, argued that Africa was injured by slavery and consequently retarded in terms of development. From his submission therefore, Pan-Africanism could be seen as the aggregation of the historical, cultural, spiritual, artistic, and scientific legacies of the Africans from the past to the present. By implication, it promotes values that are products of the African civilisation and struggles against slavery, racism, colonialism and neocolonialism. Thus, E.W. Blyden considers freedom as a value which must be fought for because Africans cannot be adequately developed amidst lack of freedom.

For Kwame Nkrumah, a foremost Pan-Africanist, African countries can only gain true, authentic and complete independence as a united people with a common goal. Thus, African liberation from the clutches of the colonial masters was uppermost in his mind. This he demonstrated by championing the formation of various African conferences and later in 1963 with other active African nationalists established the Organisation of Africa Unity (OAU) now African Union (AU). Calling for unity of African nations in the quest for the political liberation of colonial and post-colonial Africa, Nkrumah asserted boisterously that:

We need the strength of our combined numbers and resources to protect ourselves from the very dangers of returning colonialism in disguised forms. We need it to combat the entrenched force dividing our continent and still holding back millions of out booths. We need to secure total African liberation. ${ }^{[15]}$

From Nkrumah's posit, it can be deduced that the entire plan for the liberation movement must aim at three spheres, namely:

(i) Political freedom, that is, complete and absolute independence from the control of any foreign government.

(ii) Democratic freedom, that is, freedom from political tyranny and the establishment of true democracy where sovereignty is vested in the masses.

(iii) Social reconstruction, that is, freedom from poverty and economic exploitation and the improvement of social and economic conditions of the people.

More so, Pan-Africanism negates injustice, indignity, unfreedom of Africans and African Diasporas whereas it affirms unity, solidarity, pride, independence, advancement of Africa and Africans worldwide. On the dignity and freedom of Africans everywhere, Nkrumah contends that the independence of Ghana is meaningless unless it is linked with the total liberation of the continent. Consequently, Pan-Africanism as an anti-colonial struggle argues for the unity, dignity and equality of African peoples everywhere. According to B.C. Okolo, "the movement was a dynamic means to unify Africa, liberate her from colonialism, oppression, and racialism, in order to inculcate glory, and pride, and other cultural values of the African past in the then Africans."[16]

As an anti-colonial movement, however, Pan-Africanism became popular after the Pan-African congress of 1900 held in London, though, as an idea, Pan-Africanism began among African exiles abroad as far back as 1776 . As a result, it is often held that historically,

Pan-Africanism began not in the homeland but in diaspora.... It had its origin in the New World. It developed through what Dr. Sheperson described as a 'complicated Atlantic Triangle of influence' between the New World, Europe and America. ${ }^{[17]}$

By and large, there were seven Pan-African Congresses between 1900 and 1974: The first in London (1900); the second in Paris (1919); the third in London (1921); the fourth in London (1923); the fifth in New York (1927); the sixth in Manchester (1945); the seventh in Dar-es-Salaam in Africa (1974). From 1927 onwards, fresh impetus came from a crop of African students studying abroad, the likes of Nnamdi Azikiwe, Kwame Nkrumah, Kenneth Kaunda, Jomo Kenyatta, etc. They, along with Dubois and George Padmore, were responsible for the last Pan-African congress outside Africa, in Manchester, in 1945 which was a turning point in the history of the movement as between 1945 and 1958, independence and liberation movements waxed strong in Africa, and many African countries gained independence.

2.2 Negritude: Negritude is a literal and cultural movement of social action and a philosophy of collective action developed by black intellectuals studying in Paris in the 1930s in response to a situation that alienated them and their cultural values. The term 'Negritude' comes from the Latin 'Negritudo" which means 'black colour' or 'blackness'. It assumes the total consciousness of belonging to the black race and affirms the pride in black heritage and culture. Thus, it is not a defence of skin or colour but awareness and defence of African cultural heritage. As such, it is the sum total of the values of the civilisation of the African world. Three names often associated with the foundation of Negritude as a movement are: Amie Cesaire, from Martinique, Leon Damas from Guyana, and Leopold Sedar Senghor from Senegal. However, Cesaire claims to have used the term 
'Negritude' first in a poem “Cahier d' in Retour" (Notebook of a Journey Home) in 1939: "I used the term first, that's true. But it's possible we talked about it in our group."

Negritude was a popular movement in France which transformed into an ideology for anti-colonial struggle. In it, African self assertion springs up as a reaction to the French policy of assimilation, which seeks to turn Africans into Frenchmen. Thus, as a movement, Negritude was used in fighting French political and intellectual hegemony and domination. As such, in its early stages, Negritude was "a resistance to the politics of assimilation," "19] that is, "a reaction to the racist colonialist ideology of white superiority." ${ }^{[20]}$ This was however, a necessary means in the liberation struggle of the colonised.

Negritude significantly influenced the post-independence struggles of Africans and its aims and objectives are the same as those pursued by the black African since his independence. Kwame Nkrumah, for example, is of the view that the African struggle continues even after independence and the struggle, for him, is "a fight to the death against oppression, racism, and exploitation." ${ }^{\text {[21] }}$ Obi Egbuna refers to it as the struggle for black power:

That is what black power is about. We do not want to dominate nobody. We have been maligned too long to know how bad it hurts. We just want to be left alone to man the ship of our affairs. We want to post women who wear strange wigs to Europe where they belong. We want to give black music and culture to a world prepared for it. ${ }^{[22]}$

Thus, even if it is obvious that Negritude began almost as a cultural movement, its aims, objectives and credo qualify it as a movement of anti-colonial struggle since it repudiates oppression and racism but affirms blackness and the ideas and aspirations of the Blackman. In fact, as a socio-political movement, Negritude is a ceaseless struggle for the Blackman since independence.

It is pertinent to note, however, that Negritude has received diverse criticisms. For instance, it has been criticised as lacking grassroots appeal unlike Pan-Africanism. Wole Soyinka, particularly, has repudiated Negritude as an anti-colonial movement on the ground that a tiger does not proclaim its tigerness but acts like one in the presence of danger or its prey. Thus, Negritude is not a safe ideology for promoting being black, instead it should emphasise acting black in the midst of threats to black existence and cultural values. Nkrumah also criticised Negritude that it is a mere literary affection and style which piles up words with occasional reference to Africa.

Despite the criticisms put forward against Negritude, there is no gainsaying that it was an anti-colonial African ideology which nurtured the African dream and struggle for independence, since it launched revolts against racism, oppression and colonialism and fought for the collective freedom of Africans.

\section{The Realisation Of Independence In Africa And The Emergent Problems}

Realizing that they were persons of the same race, a common historical background, a common identity, whose culture, wealth and personality had been abused by the same common enemy - the Whiteman the Africans unanimously initiated a struggle for political liberation and the right of the Africans to be free and independent. They adopted political resolutions in the form of nationalist ideologies as we have discussed above. B.C. Okolo observed that these resolutions "were strongly anti-imperialistic in character, demanding the right of Africans to choose their own governments and urging Africans to struggle unitedly for this and other aims by all means at their disposal, even by forcible means." $" 23]$

Consequently, between 1945 and 1958 independence and liberation movements waxed strong in Africa as many African countries gained the awaited independence. There was the 1952 national revolution in Egypt, the independence of Sudan in 1956, Morocco and Tunisia also gained independence in 1956, Ghana in 1957, Guinea in 1958, and then the whole former French Africa. Then, Nigeria, Kenya, Sierra Leone, Uganda, Tanzania and others won their political independence from 1960 onwards.

Having realised the long-sought political freedom of Africa, there were different faces of abuse of this freedom. Africa, since independence, has not been able to rule herself, and so numerous problems bedevil the independence achieved. It is sad and ironic therefore that Africa's transition from colony to nation-states could not translate into freedom rather it created a historical vacuum of unfulfilled dreams of the independence achievements. Instead of nurturing and fortifying the freedom that came with African independence, the same Africans meted virulent abuses on this golden freedom. As such, in the immediate-independent Africa, it was observed that:

The oppressive class configuration which colonialism epitomised, in essence, remains intact, as direct colonial presence was effectively replaced with indigenous clones. Not only did strife ensue ... repression returned and [political] opposition was once more anathematised, often with a crudity and brutality equalling the barbarism of colonialism. ${ }^{[24]}$ 
As Frantz Fanon rightly observed in his book, The Wretched of the Earth, the leaders of the African liberation movement whom he called the "Nationalist bourgeoisie" and who took over the leadership of Africa from the colonisers at independence are those who have been trained and immersed in the thinking and system of the Whiteman. For Fanon, the native is an oppressed person whose permanent dream is to become the persecutor. ${ }^{[25]}$ As such, the anti-colonial articulators stepped into the corridors of African leadership only to construe the general freedom for individual and selfish aims to the detriment of the masses. They sought class distinction like their colonial masters, assimilated the colonisers' mentality and considered themselves superior to their own people.

Furthermore, the internally induced problems that came with African independence escalated beyond range. The struggle for independence and the anxiety to return to self-rule earned for the African people a class of unsuspected nationalists (petit-bourgeoisies) who championed the independence struggle for ulterior motives and overall self-interest. While the African peoples expected independence to bring about a qualitative change in their lives, the nationalists perhaps have a different agenda altogether. In fact, it has been argued that they were more interested in "replacing Europeans in the leading positions of power and privileges," [26] at the expense of the desperately needed "radical transformation of the state and society.",27]

Thus, with the termination of colonial rule, the notion of politics in Africa transformed for the worse. From a struggle and concerted effort to achieve a qualitative change in the lives of the African masses, African politics transformed into "the struggle to control and exploit the offices of the state" ${ }^{[28]}$ by even dubious and violent means. Thus, in the immediate independent Africa, the people became captives as it was under colonial rule, but to their own leaders, who marginalised and manipulated them for self-aggrandisement.

\section{The Incident Of Military Coups And Regimes In Post-Colonial Africa}

In the face of the abuse of the political freedom gotten, premium was placed on power in African politics and as one would expect, the military intervened in the misgovernance of many African states. As a result, Africa's first military coup took place in Togo in 1952. Abdel Nazer of Egypt justifies this coup and subsequent military coups arguing that:

It was not the army that determined the role it was to play in the course of events.

The reverse was nearer to the truth. It was events and their development that determined the army's part in the supreme struggle for the liberation of the homeland. ${ }^{[29]}$

However, rather than solving the political crisis which has engulfed Africa, the military further compounded the problem. No wonder Chris Uroh is convinced that the military has performed better than civilians in looting in the name of governance in Africa as well as furthering the political upheaval of Africa:

Political soldiering with its characteristic absence of consultations with the governed by those in authority, general high handedness, budgetary indiscipline, absence of accountability and so on, has in fact, compounded the problem and further deepened the crisis of political legitimacy in Africa. ${ }^{\text {[30] }}$

Claude Ake explained the problem with military regimes in Africa stating that "once the military assumes power, that is, enters politics, politics captures it and it immediately begins to reflect on an increasing scale the social contradictions of the society." And henceforth, he continues, "the same features which discredited the civilian political formation and political regime begins to assert themselves on the military." [31] As a result, military rulership in Africa has been caught in a dilemma of neither solving the problem nor vacating the political space. And so, political power in Africa continues to oscillate between civilian politicians and military politicians. In Nigeria, for instance, there have been eleven military regimes since her independence in 1960 and only one of them successfully handed power to his successors. Others were stamped out of office, overthrown in sometime bloody military coups. To say the truth, military regimes have really made things go wrong in the post-colonial Africa.

\section{Disillusionment And The Afro-Pessimist Thesis}

When the future looks back on ... our immediate post-colonial past it will register a rather harsh disillusionment and disappointment regarding the promise and the actuality of the immediate post-colonial African situation. ${ }^{[32]}$

Indeed Africa is beleaguered by a handful of political catastrophe which sinks it into disillusionment, disappointment and utter despair. The African impasse is aptly captured by Obi Oguejiofor that "the enormous problems of Africa are failure of states... democracies that atrophied... abuse of power and position, lawlessness." [33] The condition of Africa today is one of confused political ideologies which have taken place of the euphoria of the immediate post-independent era. In fact, harsh realities are infiltrating into the sociopolitical space of Africa as the day slips by. Therefore, it has become germane to seek viable remedies to the failure of or failing leadership in Africa. The confused ideologies in African politics amount to political instability, inefficient leadership and discontent of the masses. 
Since independence, Africans have taken as their own task, that of building a great continent out of her colonial experience. But unfortunately, efforts to achieve this goal in most countries have failed. African leaders have been unable to rise up to their responsibilities. In fact, the political landscape of post-independent Africa is replete with dictatorial figures camouflaging as political leaders and democrats, whereas many of them lack direction. They are plagued by greed, pathological egoism, rivalry, and avarice, and have failed to acknowledge and defend the sacrifices made by our heroes past.

However, the confused ideologies point to the unfulfilled dreams of the independence achievements of the 1960s. Tsenay Serequeberhan traces the origin of this confusion to the exercise of the first act of freedom that the Africans engaged in by attempting to violently disrupt the 'normality' which European colonial society presupposes. ${ }^{[34]}$ Consequently, Africa since independence has been pre-occupied with being confused rather than charting the course for a purposive leadership and development. Samir Amin observed that: If the 1960s were characterised by the great hope of seeing an irreversible process of development launched throughout what came to be called the Third World, and in Africa particularly, the present age is one of disillusionment. ${ }^{[35]}$

Furthermore, the disillusionment of the post-colonial dreams has plunged the Africans into a crisis of expectations. Practically speaking, some African countries have resorted to Marxism, or capitalism, or socialism or even African socialism as a way out of this misdemeanour. But they all have been to no avail. Consequently, Africa has no clear direction out of its lethargic inertness.

The ambiguous calamity of loss of dream and direction occasioned Afro-pessimism, a thesis which repudiates the African self-worth but emphasises that either Africa seeks external assistance or Africa is doomed. The clearest sign of this was African leaders going back to the former colonial powers to seek aid and direction. Of course, they started telling us what to do to (dis)organise us further. To start with, the African states have been reduced to producers of commodities they do not consume and consumers of products they cannot produce - a mockery of the so called independence of the African states. ${ }^{[36]}$ This demonstrates clearly that the attainment of independence by African states did not cut off the umbilical cord of political dependency with which they were tied to the western world.

Moreover, on the request for the way forward, the former colonial powers packaged unfavourable programmes like Structural Adjustment Programme (SAP) and urged it upon Africa countries. This, in fact, is a destabilisation formula pushed down the throat of the gullible African leaders. For example, despite the contradictory and illogical argument of SAP, as Chris Uroh has argued, ${ }^{[37]}$ it has won the hearts of many African leaders and they have pursued this disruptive policy blindly. A cursory look at African attempts to imbibe SAP reveals that it has not yielded the purported development of Africa. Adebayo Adedeji, a renowned economist, believes that:

Far from bringing about economic reform, these Structural Adjustment Programmes have severely eroded the development drive that has always been the best hope for stabilising the precarious political structures that succeeded colonialism. ${ }^{[38]}$

From the foregoing, it is obvious that the disillusionment of the post-colonial African dream allowed Afropessimism to creep in and this in turn worsen the political dependence of Africa which supposedly has been ousted by African independence. Consequently, the quest for political liberation in post-colonial Africa has been truncated and dislocated. Yes, the freedom was gotten but it was papered over layers of dependencies in the aspects of culture, language, education, economy, religion and social life - the defining factors of a people or personality. Due to this overwhelming dependency, we could no longer execute and defend the acquired political freedom because there was lack of an African background in almost all aspects of life for this freedom to be planted and instituted. And so, the political freedom failed to yield an all-round just as lack of freedom in other aspects failed to yield the desired political freedom. Therefore, the best story to be said about the journey to African political freedom is one of loss of direction and a vicious circle.

\section{A Philosophical Analysis Of The Role Of The 'Indigenous' In The Re-Making Of Africa}

Generally, analysis is a process of investigation into the structure, functioning and connections of a particular matter under scrutiny, such that issues that are enveloped, concealed, compounded and latent in facts are made open and pure. But philosophical analysis "is a method of inquiry in which one seeks to assess complex systems of thought by 'analysing' them into simpler elements whose relationships are thereby brought into focus." [39] Thus, philosophical analysis moves from the factual to the theoretical or abstract, from a common knowledge of facts which constitute our data but are complex, vague and relatively concrete to the simple, precise and abstract in order to derive a logical guarantee of the facts concerned. In short, analysis is fundamental to philosophy and philosophers over the ages have embraced it as an indispensible method of 
philosophy. However, since this work has exposed factual facts on the African political struggle, it is imperative to analyse the facts before us so as to glean a deeper understanding and rectification of the African quagmire.

First and foremost, there is need to re-consider the term 'independence.' The term 'independence' is broader than the mere political liberation emphasised and pursued by the African nationalists and thinkers. African dependence on the colonial powers was in all ramifications - political, economic, social, religious, cultural, moral, etc. And to further strengthen the bonds of this dependence, in the transition from colonial to post-colonial Africa, the colonisers have cloned political scientists (in this case, the nationalists), economists, sociologists, religious leaders, etc, in their own fashion among us. All these have bearing on the psyche and mentality of the Africans who have engaged in self-deceit of chasing the Europeans out of Africa yet retained and strive to transfer Europe to Africa. Reflecting on this irony, Kofi Awoonor submits that:

...material dependence is buttressed by mental dependence. Physical dependence is underwritten by a strong superstructure of ideas and concepts, which affirms that we are inferior, stupid, our African ways primitive and we can only proceed under the tutelage of our historical conquerors. ${ }^{[40]}$

Meanwhile, the African nationalists are myopic on the reality and implications of independence. The concept of freedom which they sought was too narrow; political freedom would not be realistic without cultural freedom and others. Thus, they neglected pursuing altruistic freedom on which the political freedom would gain firm footing. The result is, and has been, that the absence of peculiarity of the African environment has failed to usher in the developmental Eldorado anticipated in the independent Africa. Here lies the frustration of the Africans who were urged to seek first political kingdom and economic development will be added almost immediately. Today, as we have it, neither a political kingdom nor economic development is yet feasible.

The questions that come to mind at this juncture are: Was it only political dependence we suffered? Is it only political independence we require? Africa, for instance, also suffered mental degradation. Kofi Awoonor argues in this regard that:

Our continent is in deep crisis, which has a historical genesis. The dislocation of our original social, political and cultural institutions through a well-crafted programme of violence has imposed on us a degree of confusion, sometimes bordering on psychic trauma and sheer dysfunction. ${ }^{[41]}$

What has been done about this?

Furthermore, analysis of a problem determines the analysis of the solution. Now, let us weigh the nationalists' conception of the problem. If they got the problem right, then they got the solution right. But if they got the problem wrong, they got the solution wrong. So, did the nationalists in their struggles conceive the challenge of post-colonial Africa clearly? Of course, no. The problem was more than they conceived. The problem was a hotchpotch of political, cultural, linguistic, economic, social, and religious problems. If they got it right, for example, the elders and sages in Africa would have had a place in government and not just anybody who has learnt the European creed all in the name of studying political science or democracy. What about some countries like Malaysia which flaunt traditional rulers as monarchs and heads of states? Indeed there is a gap between brilliant research papers and the search for an appropriate political system rooted in history and culture.

By implication, the African state, recreated at independence, was not founded on an African platform to enable the achievement of the independence ideas. The state and its system were not founded on African culture and context. This triggers the clarion call to explore the role of the 'indigenous' in the re-making of Africa. Thus, the political system should be African in nature and context, and it requires indigenous culture, economy, education and language, etc, as its basis for operation.

Above all, there is the need to question the different philosophical and political ideologies advanced by the nationalist movement. Do these ideologies contain the required condiments? Although these ideologies were intended by them to produce the envisaged African state, the African state they conceived, as noted already, was not founded on an African platform. Considering that Africa, then and now, covers a vast mass of rural communities consisting more of illiterate people, were these ideologies really meant for such an audience?

\section{Conclusion}

It is surprising, and in fact challenging, that Africa is yet to critically examine the extent to which the inherited colonial arrangement can solve the African problem. Of course, the post-independent Africa is woven on the fabrics of the colonial arrangement. The ultimate question here is: Is there a standing critique on some of the assumptions underlying the inherited colonial or alien legacies? In response to this question, this paper is raising a passionate suspicion that the values that sustain the west may not be or are not the same that will sustain Africa.

In conclusion, it should be taken into cognisance that even though there are things to borrow from the Whiteman, ${ }^{[42]}$ Africa cannot do anything in respect of political liberation or even development in all its facets without a firm ground of the African worldview. 


\section{References}

[1]. E.C. Eze, "Modern Western Philosophy and African Colonialism," in E.C. Eze (ed), African Philosophy: An Anthology, (USA: Blackwell Publishers Ltd., 1998), 213.

[2]. A. Mazrui, The African: A Triple Heritage, (Boston: Little Brown and Company, 1986), 14.

[3]. J. Woddis, Introduction to Neo-Colonialism, (New York: International Publishers, 1967), 14

[4]. Ibid., p.15.

[5]. A. Ahmad, "The Politics of Literary Postcoloniality," Race and Class, Vol.36, no.3, 1995, 7.

[6]. A. Irele, "The Crisis of Legitimacy in Africa," Dissent, (summer), 1992, 299.

[7]. T. Serequeberhan, "Philosophy and Post-Colonial Africa," in E.C. Eze (ed) African Philosophy: An Anthology, 9.

[8]. G. Nzogola-Ntalaja, Revolution and Counter-Revolution in Africa: Essays in Contemporary Politics, (London and New Jersey: Institute for African Alternative with Zed Books Ltd., 1987), 76.

[9]. J.F.A. Ajayi, "Expectations of Independence," Daedalus, Vol. III, No.2, 1982, 5.

[10]. F. Fanon, The Wretched of the Earth, Preface by Jean-Paul Sartre, (Harmondsworth: Penguin Books, 1963$), 15$.

[11]. C. Ake, The Political Economy of Crisis and Underdevelopment in Africa: Selected Works of Claude Ake, Julius Ihonvbere (ed), (Lagos: JAD Publishers Ltd., 1989), 52.

[12]. G. Padmore, Pan-Africanism or Communism, (New York: Anchor Books, Double-Day, 1972), 83

[13]. B.C. Okolo, "Pan-Africanism as a Concept and Social Philosophy" in African Social and Political Philosophy: Selected Essays, by B.C. Okolo, (Nsukka: Falladu Publishing Company, 1993), 143.

[14]. H. Campbell (ed.), Pan-Africanism: Struggle against Neo-Colonialism and Imperialism, (Toronto: Union Labour Better Read Graphics, 1975), p.43, quoted in B.C. Okolo. "Pan-Africanism", 144.

[15]. K. Nkrumah, Africa Must Unite, (London: Panal Books, 1963), 216.

[16]. Okolo, "Pan-Africanism," 146.

[17]. Colin Legum, Pan-Africanism: A Short Political Guide, (New York: Federick A. Praeger, 1962), 15, quoted in Okolo "PanAfricanism," 147.

[18]. A. Cesaire, Discourse on Colonialism, Tr., Joan Pinknam, (New York: Monthly Review Press, 1972), 72, quoted in Okolo, 61.

[19]. Ibid.

[20]. R. Zahar, Frantz Fanon, "Colonialism, Philosophy, Alienation”, Tr., W.F. Feuser, (New York: Monthly Review Press, 1974), 64, quoted in Okolo, 62.

[21]. K. Nkrumah, The Spectre of Black Power, (London: Panaf Books, Third Impression, 1970), 5, quoted in Okolo, 69.

[22]. O.B. Egbuna, The ABC of Black Power Thought, (Lagos: A Grassroots Book, $2^{\text {nd }}$ Printing, 1978), 6-7, quoted in Okolo, 69.

[23]. Okolo, Op. Cit., 149.

[24]. O. Oguibe, ed., Sojourners: New Writings by Africans in Britain, (London: Africa Refugee Publishing Collective, 1994), xiv-xv.

[25]. See Frantz Fanon, The Wretched of the Earth, (New York: Grove Press, 1968), especially the Chapter on "The Pitfalls of National Consciousness."

[26]. Nzogola-Ntalaja, Revolution and Counter-Revolution in Africa, 76.

[27]. Ibid.

[28]. R. Joseph, Democracy and Prebendal Politics in Nigeria, (Ibadan, Owerri, Kaduna: Spectrum Books Ltd., 1991$), 3$.

[29]. A. Nazer, "The Philosophy of the Revolution" in G.M. Mutiso and S.W. Rohio (eds.), Readings in African Political Thoughts, (London: Heinemann, 1975), 501.

[30]. C. Uroh (ed.), Africa and the Challenge of Development: Essays by Samir Amin, (Ibadan: Hope Publications, 1998), 16.

[31]. Ake, The Political Economy, 57.

[32]. T. Serequeberhan, "Philosophy and Post-Colonial Africa," 10.

[33]. J.O. Oguejiofor (ed.), Philosophy, Democracy and Responsible Governance in Africa, Vol. I, (London: Transactional Publishers, 2003), xiii.

[34]. T. Serequeberhan, "Philosophy and Post-Colonial Africa," 235

[35]. S. Amin, Maldevelopment: Anatomy of Global Failure, (Tokyo, London, Jersey, United Nations: University Press and Zed Books Ltd., 1990), 1.

[36]. C. Uroh (ed.), Africa and the Challenge of Development, 10

[37]. See C. Uroh, "Philosophy in a Milieu of Crisis: An Indictment of the Contemporary African Philosopher," A Paper Presented at an International Conference on African Philosophy, Ibadan, Nigeria, March 27-31, 1995.

[38]. A. Adedeji, "An Alternative for Africa," Journal of Democracy, Vol. 5, No.4, October, 1994, 117.

[39]. T. Baldwin, “Analytical Philosophy,” The Routledge Encyclopedia of Philosophy, (London: Routledge, 1998).

[40]. K.N. Awoonor, "A Socio-Cultural Proposal for African Development," in JBAAC: Journal of Black and African Arts and Civilisation, Vol. 1, No. 1, (Lagos: Centre for Black and African Arts and Civilisation, 2001), 15-16.

[41]. Ibid., 11

[42]. Kwasi Wiredu explains this point clearly in his "Toward Decolonisation of African Philosophy and Religion" where he argued that it would not be rational for the Africans to reject everything that comes from or is related to the Europeans. Rather, what should be jettisoned are the 'undue' influences of the Europeans on Africans. 